\title{
Isoelectric Focusing Analysis of Stylar Proteins Associated with Self-incompabibility Alleles in Japanese Pear
}

\author{
Tetsu Nakanishi ${ }^{1}$, Tadahiro Yamazaki ${ }^{1 *}$, Kanako Funadera ${ }^{1 * *}$, \\ Haruyo Tomonaga ${ }^{1 * * *}$, Takeshi Ozaki ${ }^{1}$, Yoshitaka Kawai ${ }^{1 * * * *}$, \\ Takao Ichii ${ }^{* * * * *}$, Yoshihiko Satoh ${ }^{2}$ and Akio Kurihara ${ }^{2 * * * * * *}$ \\ 1 Fruit Science Laboratory, Faculty of Agriculture, Kobe University, Kobe 657 \\ ${ }^{2}$ Fruit Tree Research Station, MAFF, Fujimoto, Tsukuba, Ibaraki 305
}

\begin{abstract}
Summary
The stylar proteins of 22 varieties of Japanese pear (Pyrus serotina Rehd., 21 selfincompatible and one self-compatible) were analyzed by isoelectric focusing-polyacrylamide gel electrophoresis (IEF-PAGE) to identify the S-allele proteins (S-proteins) associated with self-incompatibility (SI). The corresponding relationships between the protein bands and the four alleles $S_{2}, S_{3}, S_{4}$ and $S_{5}$, were examined for each variety for which the allele composition was already known.

Experiment 1 comprised the IEFs on the four major varieties. Analysis of the band patterns, isolated at intervals $\mathrm{pH} 3 \sim 10,5 \sim 8$ and $4 \sim 6.5$ revealed that three bands (hereafter, tentatively referred to as) (a) at isoelectric point (pI) 6.6 , (c) at pI 5.3 and (d) at pI 5.0 were the putative proteins corresponding to the $\mathrm{S}_{4}$ allele. Band (b) at pI 5.6 and (e) at pI 6.0 were also the putative proteins corresponding to the $S_{2}$ allele and the $S_{5}$ allele, respectively. All the bands described above exhibited a positive periodic acid Schiff's (PAS) reaction. Therefore the presence of glycoproteins was suspected. Experiment 2 comprised IEFs on the other 18 varieties. The results compiled from both experiments showed that among 21 varieties (other than one self-compatible variety), the correspondence between the bands and S-alleles was relatively high on band (c) in 19 varieties. This band was thought to be associated with the $\mathrm{S}_{4}$ allele. Other bands demonstrated rather low correspondences; band (a) exhibited the relationship in 15 varieties, band (b) in 13 varieties and band (d) in 13 varieties. No difference in protein band patterns was exhibited between the self-incompatible variety 'Nijisseiki' and its self-compatible strain 'Osa-Nijisseiki', which was assumed to be a stylar part mutant of the S-gene. Our discussion compares the results of this study with research on S-proteins in other species, and includes suggestions for future research methods.
\end{abstract}

\section{Introduction}

Japanese pear (Pyrus serotina Rehd.) has long

Received for publication 8 January 1991. This study was supported in part by Grant-in-Aid for special Research on Priority Areas (Project No. 02242102, Cellular and Molecular Basis for Reproductive Processes in Plants) from the Ministry of Education, Science and Culture, Japan.

* Present address: Sionogi \& CO., LTD.

** Present address: Hyogo Prefecture.

*** Present address: Sumitomo Chemical Company, LTD.

**** Present address: Mie University.

***** Present address: Kansai Jogakuin Junior College.

Present address: JICA, Specialist. been cultivated in Japan. Almost all varieties exhibit self-incompatibility (SI). Thus, artificial pollination is necessary, which involves much inconvenient labor.

In early research on sterility in Japanese pear, Kikuchi (1928) found that paterclinal incompatibility, when applied to cross-sterility always occurred in matings between some individuals of the $F_{1}$ generation and their pollen parent variety. Kikuchi's finding, together with the oppositional Sallele hypothesis in SI previously proposed by East and Mangelsdorf (1925) in Nicotiana, led to Terami's analysis (Terami et al., 1946) that seven Salleles $\left(\mathrm{S}_{1}-\mathrm{S}_{7}\right)$ gametophytically control SI among the varieties of Japanese pear. Terami's analyses 
resulted from many crossings between the varieties (Kikuchi, 1929; Ushigoshi and Tokuyasu, 1930; Iimori, 1933; Kawaguchi and Samune 1935). Ogaki (1958) and Machida (1972) have since analyzed the S-alleles of the varieties in the course of breeding new varieties.

The growth of incompatible pollen tubes retards at the half-way point, and stops almost at the base of the style. This is a physiological aspect of SI in Japanese pear (Asami and Hayami, 1934; Terami, 1937) and is consistent with the behavior of other gametophytic SI plant species where inhibition of the pollen tube occurs in the style (Du Nettancourt, 1977). Attempts to find a substance which inhibits the growth of the pollen tube in Japanese pear, however, have disclosed no specific substance either within the styles or the pistil (Inose, 1964; Hirata et al., 1973; Sobajima et al., 1973).

While, the multi-allelic S-gene theory explains the inheritance of SI in many plant species, Lewis (1952) and Linskens (1960) surmised that the SI reaction between pollen and pistil involves an antigenic substance specific to the S-allele.

Recently, Nishio and Hinata (1977) have used electrophoresis to show that the stigma protein in Brassica oleracea with its different isoelectric point $(\mathrm{pI})$, is associated with the S-alleles governed by the sporophytic SI system. This protein has been identified as a glycoprotein (Takayama et al., 1986) and is called an S-allele associated protein (Sprotein). It has also been identified in the styles of gametophytic SI plant species, Nicotiana alata (Bredemeijer and Blass, 1981), Lycopercicon peruvianum (Mau et al., 1986), Petunia hybrida (Kamboj and Jackson, 1986; Broothaerts et al., 1989), Petunia inflata (Ai et al., 1990), Solanum tuberosum (Kirch et al., 1989) and Solanum chacoense (Xu et al., 1990). These proteins are thought to play an important role in both the gametophytic and sporophytic SI systems because they localize in the tissue where the SI reaction occurs between pollen and pistil. The timing of the production of the Sprotein coincides with the pistil's expression of SI during flower development (Nasrallah and Nasrallah, 1986).

Lately, Takayama et al. (1987) have revealed the amino acid sequence of the S-proteins of Brassica camperrstris. Nasrallah et al. (1985) and Anderson et al. (1986) have shown the cDNA clone coding for the S-proteins of Brassica oleracea and Nicotiana alata, respectively. Kawata et al. (1990) have indicated homologous amino-acid sequences between the ribonuclease of a fungus, Aspergillus eurasia, and those in the S-protein of Nicotiana alata. McClure et al. (1989) have discovered that ribonuclease activity in the Nicotiana alata style is involved in the mechanism of S-genes.

In the above mentioned Solanaceae and Cruciferae families, knowledge of S-proteins on the molecular level abounds. In contrast, such knowledge is scant for the Rosaceae family, Prunus avium (Mau et al., 1982), including Japanese pear (Hiratsuka et al., 1986).

Despite the large number of genetic analyses of Japanese pear varieties in the past, few attempts have been made to ascertain the S-proteins in the style. Therefore, we have examined the stylar proteins in Japanese pear. Preliminary analysis using sodium dodecyl sulfate-polyacrylamide gel electrophoresis (SDS-PAGE) showed that most proteins separated within an approximate range of 20,000 to 50,000 in molecular weight. These proteins were too concentrated to distinguish, or to subject to analysis with S-alleles. Thus, the present research attempts to analyze the S-proteins by isoelectric focusing-polyacrylamide gel electrophoresis (IEF-PAGE), and concentrates on the correspondence between the S-alleles and the stylar proteins obtained from 22 varieties of Japanese pear.

\section{Materials and Methods}

\section{Plant materials}

Flowers from 22 varieties of Japanese pear which have various $\mathrm{S}$-alleles were collected from five orchards during the flowering season. Fourteen varieties, 'Doitsu', 'Yakumo', 'Meigetsu', 'Ichiharawase', 'Imamuraaki', 'Wasechojuro', 'Rokugatsu', 'Gion', 'Hayatama', 'Taihaku', 'Kiyozumi', 'Waseaka', 'Asahi' and 'Okusankichi' came from the Fruit Tree Research Station, Ministry of Agriculture, Forestry and Fisheries (Ibaraki Prefecture, Tsukuba). Three varieties, 'Chojuro', 'Kosui' and 'Shinsui', came from the Kobe University Experimental Farm (Hyogo Prefecture, Kasai). Two varieties, 'Hakko' and 'Kikusui', came from the Hyogo Prefectural Agricultural Station (Kobe). 'Osa-Nijisseiki' and 'Nijisseiki' came from the orchard of Kobe University (Kobe) and the orchard 
Table 1. S-genotypes of Japanese pear varieties used in both Experiments 1 and 2.

\begin{tabular}{ll}
\hline Variety & $\mathrm{S}_{\text {alleles }}{ }^{z}$ \\
\hline Doitsu & $\mathrm{S}_{1} \mathrm{~S}_{2}$ \\
Hayatama & $\mathrm{S}_{1} \mathrm{~S}_{2}$ \\
Yakumo & $\mathrm{S}_{1} \mathrm{~S}_{4}$ \\
Meigetsu & $\mathrm{S}_{1} \mathrm{~S}_{5}$ \\
Ichiharawase & $\mathrm{S}_{1} \mathrm{~S}_{5}$ \\
Imamuraaki & $\mathrm{S}_{1} \mathrm{~S}_{6}$ \\
Chojuro & $\mathrm{S}_{2} \mathrm{~S}_{3}$ \\
Wasechojuro & $\mathrm{S}_{2} \mathrm{~S}_{4}$ \\
Rokugatsu & $\mathrm{S}_{2} \mathrm{~S}_{4}$ \\
Gion & $\mathrm{S}_{2} \mathrm{~S}_{4}$ \\
Kikusui & $\mathrm{S}_{2} \mathrm{~S}_{4}$ \\
Nijisseiki & $\mathrm{S}_{2} \mathrm{~S}_{4}$ \\
Osa-Nijisseiki & $\mathrm{S}_{2} \mathrm{~S}_{4}{ }^{\mathrm{m}}$ \\
Taihaku & $\mathrm{S}_{4} \mathrm{~S}_{5}$ \\
Hakko & $\mathrm{S}_{4} \mathrm{~S}_{5}$ \\
Kosui & $\mathrm{S}_{4} \mathrm{~S}_{5}$ \\
Shinsui & $\mathrm{S}_{4} \mathrm{~S}_{5}$ \\
Kiyozumi & $\mathrm{S}_{4} \mathrm{~S}_{5}$ \\
Waseaka & $\mathrm{S}_{4} \mathrm{~S}_{5}$ \\
Asahi & $\mathrm{S}_{4} \mathrm{~S}_{5}$ \\
Seiryu & $\mathrm{S}_{4} \mathrm{~S}_{5}$ \\
Okusankichi & $\mathrm{S}_{5} \mathrm{~S}_{7}$ \\
\hline
\end{tabular}

" S-allele compositions of each variety are cited from the genetic analysis by Terami et al. (1976), Ogaki (1958), Machida (1972) and Satoh et al. (1988).

of Mr. Tanigawa (Hyogo Prefecture, Kasai), respectively. The list of the varieties with reference to the respective S-alleles is shown in Table 1. To preclude pollination, flowers were collected during the balloon bud stage, $1 \sim 2$ days before flowering. Styles were cut at their base and then immediately frozen on dry ice and kept at $-80^{\circ} \mathrm{C}$ until protein extraction.

\section{Extraction and purification of proteins from the style}

The styles of 400 flowers (approximately $1 \mathrm{~g}$ fresh weight) were finely ground in a pestle with $150 \mathrm{mg}$ insoluble polyvinyl pyrrolidone (PolyclarAT) and liquid nitrogen. Then $40 \mathrm{ml}$ of phosphate buffer with reducing agents $(50 \mathrm{mM}$ phosphate buffer, $\mathrm{pH} 7.0,10 \mathrm{mM}$ DTT and $0.1 \% \mathrm{~L}$-sodium ascorbate) was added and the mixture stirred on ice. These operations were performed in a chamber filled with nitrogen gas to prevent browning due to polyphenols. The homogenate was centrifuged at $4^{\circ} \mathrm{C}, 9,000 \mathrm{~g}$ for $20 \mathrm{~min}$. Polyphenols were removed using a DEAE-cellulose column as described by Takeo and Uritani (1976). The supernatant was eluted by adding two column volumes of $50 \mathrm{mM}$ phosphate buffer solution (including reducing agents) to the DEAE-cellulose column. The eluted solution was dialyzed against distilled water at $5^{\circ} \mathrm{C}$ for $48 \mathrm{hr}$ and lyophilized. The sample was kept in a freezer at $-20^{\circ} \mathrm{C}$ until use for IEF.

During the removal of polyphenols from the style extract, secondary proteins were again eluted by $1 \mathrm{M} \mathrm{NaCl}$ from the DEAE-cellulose column in the preliminary examination following elution with phosphate buffer. The amount of the protein from the second elution was slight and no significant difference in IEF patterns was detected compared with proteins which were first eluted by phosphate buffer. Furthermore, dialyzation of the elutant was required to distinguish the protein bands avoiding distortions during IEF, although slight modification of the proteins was inevitable.

\section{IEF-PAGE}

IEF was performed at three $\mathrm{pH}$ intervals of 3 to 10,5 to 8 and 4 to 6.5 . A $5 \%$ polyacrylamide slab gel $(110 \times 110 \mathrm{~mm}, 0.5 \mathrm{~mm}$ thick $)$ containing $2 \%$ pharmalyte with $\mathrm{pH}$ interval of 3 to 10,5 to 8 or 4 to 6.5 was prepared. The sample was placed directly on top of the gel using a sample applicator. Then, focusing was performed for $90 \mathrm{~min}$ at $7.5 \mathrm{~W}$ fixed power.

Coomassie Brilliant Blue staining: After focusing, the gel was fixed in a solution of $10 \%$ trichloroacetic acid and $5 \%$ sulphosalicylic acid for $30 \mathrm{~min}$. For $\mathrm{pH}$ control, the gel was immersed for 1 day in a solution (acetic acid: ethanol: distilled water, $1: 3: 8$ ), then stained with $0.1 \%$ Coomassie Brilliant Blue R 250 in the solution for $30 \mathrm{~min}$. Then the gel was destained at $40^{\circ} \mathrm{C}$ for $30 \mathrm{~min}$.

Periodic acid Schiff's (PAS) staining: PAS staining was performed by the Zacharius et al. (1969) method. The gel was fixed for $30 \mathrm{~min}$ in a solution of $10 \%$ trichloroacetic acid and $5 \%$ sulphosalicylic acid, immersed in $7.5 \%$ acetic acid at room temperature for $1 \mathrm{hr}$, and reacted with chilled Schiff's reagent for $45 \mathrm{~min}$. Excess stain was removed in $10 \%$ acetic acid at room temperature, changing the solution three times, every $30 \mathrm{~min}$. 


\section{Results}

\section{Experiment 1. IEF-PAGE analysis of four major varieties}

The first experiment attempted to determine the correspondences between bands and the S-alleles for the four major varieties, viz. 'Chojuro' $\left(\mathrm{S}_{2} \mathrm{~S}_{3}\right)$, 'Nijisseiki' $\left(\mathrm{S}_{2} \mathrm{~S}_{4}\right)$, 'Kosui' $\left(\mathrm{S}_{4} \mathrm{~S}_{5}\right)$ and 'Shinsui' $\left(\mathrm{S}_{4} \mathrm{~S}_{5}\right)$. This study of correspondences was determined by whether or not common bands existed among the types of S-alleles of these four varieties. For instance, in the bands corresponding to the $S_{2}$ allele, commonality exists between the $\left(\mathrm{S}_{2} \mathrm{~S}_{3}\right)$ and $\left(\mathrm{S}_{2} \mathrm{~S}_{4}\right)$ varieties but not in the $\left(\mathrm{S}_{4} \mathrm{~S}_{5}\right)$ varieties.

IEF-PAGE for $\mathrm{pH} 3$ to $\mathrm{pH}$ 10: The $\mathrm{pH}$ interval from 3 to 10 for IEF-PAGE covers the broadest $\mathrm{pH}$ range. Therefore, the initial analysis of this $\mathrm{pH}$ interval would show the general profile of style proteins for Japanese pear. For each variety more than 50 bands were observed (Fig. 1). They consisted of approximately 15 dense and 35 diffuse bands (hereafter called major and minor bands, respectively). A large number of bands focused between pI 4.5 to 7.35 . A particularly large number

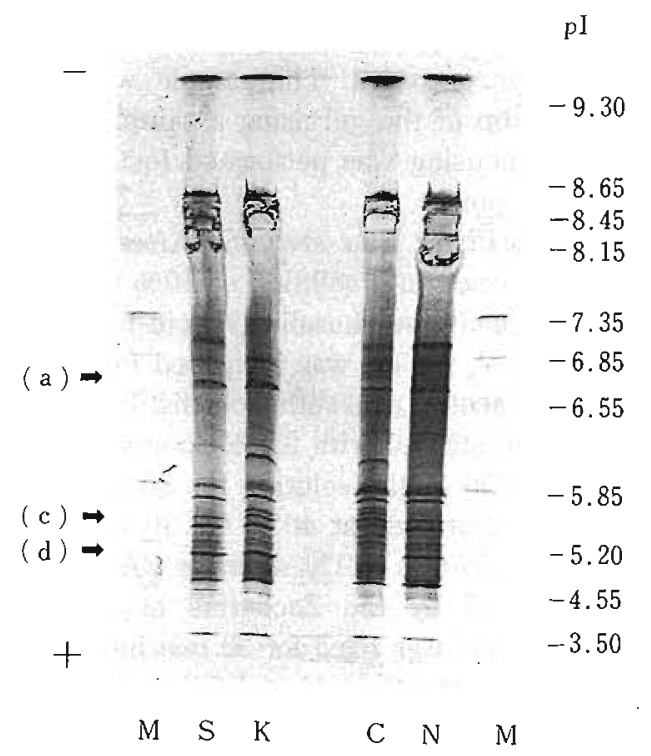

Fig. 1. IEF-PAGE (pH 3-10) profiles of the stylar proteins of four major varieties of Japanese pear. Lane $\mathrm{M}$; pI markers, $\mathrm{S}$; 'Shinsui' $\left(\mathrm{S}_{4} \mathrm{~S}_{5}\right), \mathrm{K}$; 'Kosui' $\left(\mathrm{S}_{4} \mathrm{~S}_{5}\right), \mathrm{C}$; 'Chojuro' $\left(\mathrm{S}_{2} \mathrm{~S}_{3}\right)$ and $\mathrm{N}$; 'Nijisseiki' $\left(\mathrm{S}_{2} \mathrm{~S}_{4}\right)$. Bands (a), (c) and (d) marked with arrows correspond to the $S_{4}$ allele. of bands focused between pI 4.5 to 5.85 . In this range, the bands found near pI 5.0 seem to correspond to an $S_{4}$ allele in 'Nijisseiki', 'Kosui' and 'Shinsui'. A band corresponding to an $\mathrm{S}_{2}$ allele in 'Chojuro' and 'Nijisseiki' was also evident near pI 5.6. The bands at pI 6.6 were common to the three varieties. A single band also focused near each of the electrodes. These bands might consist of unseparated proteins with pIs either below pI 3.5 or near pI 10 . In particular, the band on the basic side most probably has a high content of strongly basic proteins with pIs higher than pI 9.

IEF-PAGE for $p H 5$ to $p H$ 8: The band concentrated near $\mathrm{pI} 6.6$ corresponded to the $\mathrm{S}_{4}$ allele in 'Nijisseiki', 'Kosui' and 'Shinsui' (hereafter tentatively called the (a) band) (Fig. 2). Also, the band near pI 6.0, although a considerably thin band, corresponded to the $\mathrm{S}_{5}$ allele in 'Shinsui' and 'Kosui' (hereafter called the (e) band).

IEF-PAGE for $\mathrm{pH} 4$ to $\mathrm{pH} 6.5$ (Coomassie Brilliant Blue and $P A S$ staining): Examining this band pattern for S-allele correspondence confirmed that the pI of the (a) band, corresponding to the $\mathrm{S}_{4}$ allele in 'Nijisseiki', 'Kosui' and 'Shinsui', is 6.6 (Fig.

pI

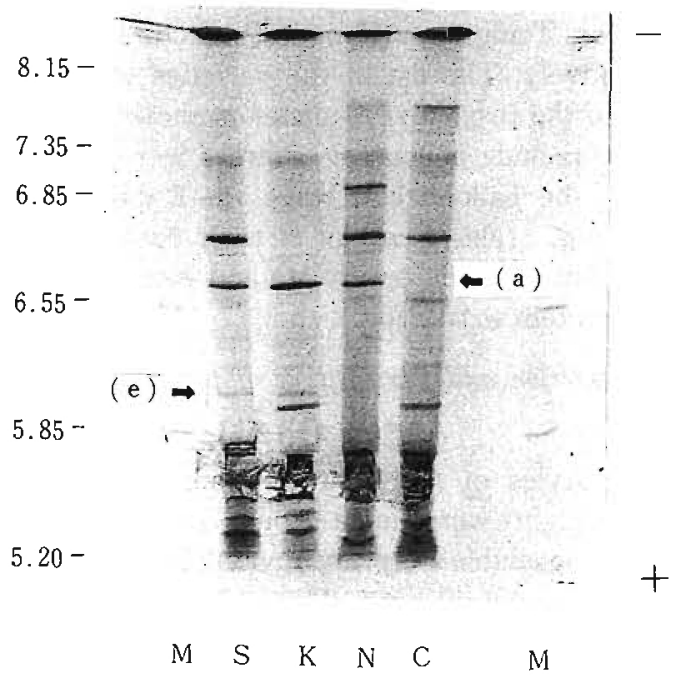

Fig. 2. IEF-PAGE ( $\mathrm{pH} 5-8$ ) profiles of the stylar proteins of four major varieties of Japanese pear. Lane $\mathrm{M}$; pI markers, S; 'Shinsui' $\left(\mathrm{S}_{4} \mathrm{~S}_{5}\right)$, K; 'Kosui' $\left(\mathrm{S}_{4} \mathrm{~S}_{5}\right)$, N; 'Nijisseiki' $\left(\mathrm{S}_{2} \mathrm{~S}_{4}\right)$ and $\mathrm{C}$; 'Chojuro' $\left(\mathrm{S}_{2} \mathrm{~S}_{3}\right)$. Bands (a) at pI 6.6 and (e) at pI 6.0 correspond to $S_{4}$ and $S_{5}$ alleles, respectively. 


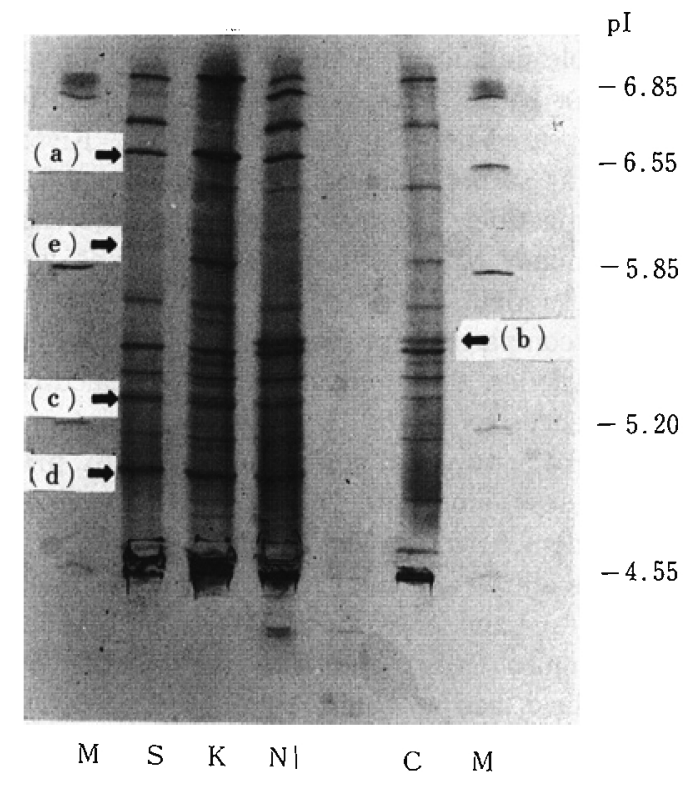

Fig. 3. IEF-PAGE (pH 4-6.5) profiles of the stylar proteins of four major varieties of Japanese pear. Lane M; pI markers, S; 'Shinsui' $\left(\mathrm{S}_{4} \mathrm{~S}_{5}\right), \mathrm{K}$; 'Kosui' $\left(\mathrm{S}_{4} \mathrm{~S}_{5}\right)$, N; 'Nijisseiki' $\left(\mathrm{S}_{2} \mathrm{~S}_{4}\right)$ and C; 'Chojuro' $\left(\mathrm{S}_{2} \mathrm{~S}_{3}\right)$. Bands (a) at pI 6.6, (c) at pI 5.3 and (d) at $\mathrm{pI} 5.0$ correspond to the $\mathrm{S}_{4}$ allele. Bands (b), at pI 5.6 and (e) at pI 6.0 correspond to the $S_{2}$ and the $S_{5}$ alleles, respectively.

3). The bands detected near pI 5.3 and 5.0 also corresponded to the $\mathrm{S}_{4}$ allele as well as band (a) (hereafter called the (c) and (d) bands, respectively). At pI 5.6 there was a band (hereafter called the (b) band) which corresponded to the $S_{2}$ allele in 'Chojuro' and 'Nijisseiki'. Furthermore, the (d) and (b) bands tend to dissolve and become faint if destaining time is lengthy after staining. This tendency is particularly strong in the (b) band.

Thus far, many $S$ proteins are reported to be glycoproteins. Thereafter, in this experiment PAS staining was also attempted (Fig. 4). Among the bands corresponding to S-alleles, the (a) and (c) bands were PAS-positive proteins. The (b) band took the stain, but lost it during destaining. Characteristically, the (b) band dissolves easily, even with Coomassie Brilliant Blue staining. Thus, the (b) band is considered PAS positive. In addition to the four bands above, other bands had positive PAS staining. However, no correspondences to S-alleles emerged.

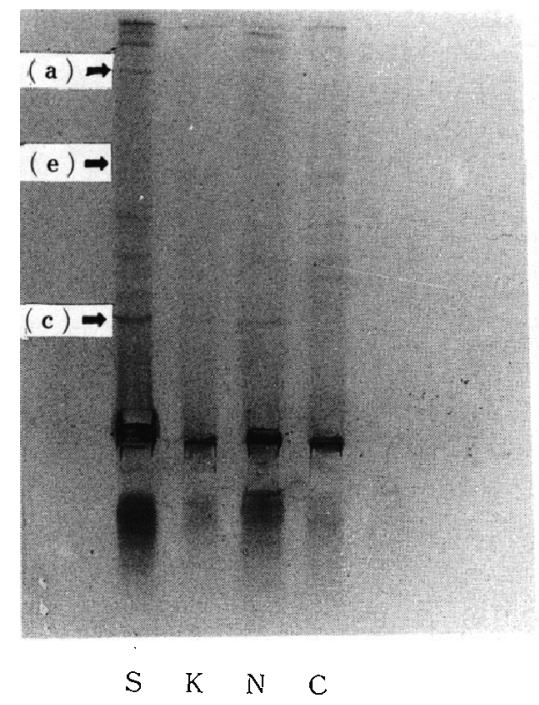

Fig. 4. PAS staining of the protein bands separated by IEFPAGE (pH 4-6.5) of four major varieties of Japanese pear. Lane S; 'Shinsui' $\left(\mathrm{S}_{4} \mathrm{~S}_{5}\right)$, K; 'Kosui' $\left(\mathrm{S}_{4} \mathrm{~S}_{5}\right) \mathrm{N}$; 'Nijisseiki' $\left(\mathrm{S}_{2} \mathrm{~S}_{4}\right)$ and $\mathrm{C}$; 'Chojuro' $\left(\mathrm{S}_{2} \mathrm{~S}_{3}\right)$. Bands (a), (c) and (b) are positive for the PAS staining.

\section{Experiment 2. IEF-PAGE analysis for 18 varieties}

The results of Experiment 1, led to IEF-PAGEs on 18 varieties from $\mathrm{pH} 4$ to $\mathrm{pH} 6.5$ and from pH 5 to pH 8. Fig. 5 shows the analysis, one of those carried out with 18 varieties, from $\mathrm{pH} 4$ to $\mathrm{pH}$ 6.5. The dense, major bands gathered and formed a pattern (Fig. 6). On this basis, investigation proceeded to the relationships between the bands with their high correspondences to the $\mathrm{S}$ alleles among 21 varieties except self-compatible 'Osa-Nijisseiki'. This experiment was carried out on the (a) (pI 6.6), (c) (pI 5.3) and (d) (pI 5.0) bands corresponding to the $\mathrm{S}_{4}$ allele and on the (b) (pI 5.6) band which corresponds to the $S_{2}$ allele respectively, but not on the (e) (pI 6.0) band with its correspondence to the $S_{5}$ allele, because of its characteristic, diffuse staining.

The (a) band appeared in nine varieties which have the $S_{4}$ allele. In five of the varieties, however, the (a) band appeared unless they have no $\mathrm{S}_{4}$ allele, viz. 'Doitsu' $\left(\mathrm{S}_{1} \mathrm{~S}_{2}\right)$, 'Hayatama' 


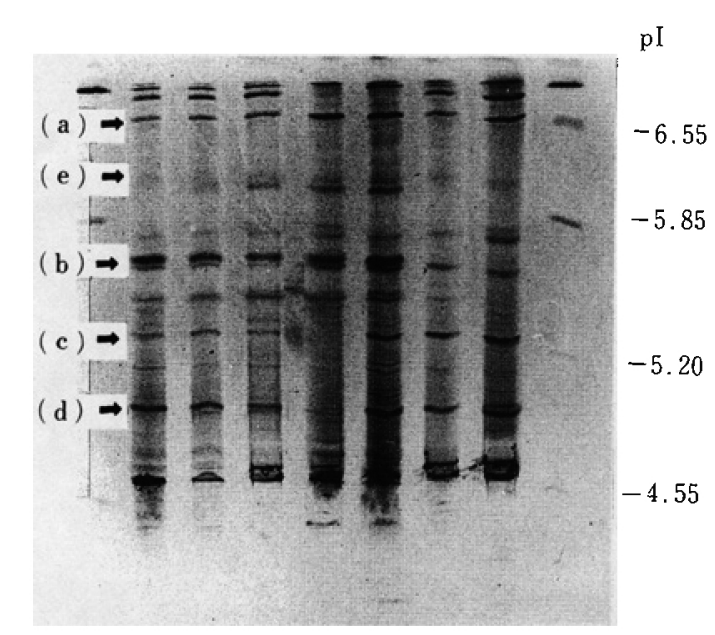

$\begin{array}{llllllllll}M & O S & N & K S & R & H & S & K Z & M\end{array}$

Fig. 5. IEF-PAGE (pH 4-6.5) profiles of the stylar proteins of several varieties of Japanese pear. This gel plate is one of those carried out with 18 varieties of Japanese pear of Experiment 2. Lane OS; 'Osa-Nijisseiki' $\left(\mathrm{S}_{2} \mathrm{~S}_{4}{ }^{\mathrm{mm}}\right.$, sm stylar part mutant), N; 'Nijisseiki' $\left(\mathrm{S}_{2} \mathrm{~S}_{4}\right)$, KS; 'Kikusui' $\left(\mathrm{S}_{2} \mathrm{~S}_{4}\right), \mathrm{R}$; 'Rokugatsu' $\left(\mathrm{S}_{2} \mathrm{~S}_{4}\right), \mathrm{H}$; 'Hakko' $\left(\mathrm{S}_{4} \mathrm{~S}_{5}\right)$, S; 'Shinsui' $\left(\mathrm{S}_{4} \mathrm{~S}_{5}\right)$, $\mathrm{KZ}$; 'Kiyozumi' $\left(\mathrm{S}_{4} \mathrm{~S}_{5}\right)$ and $\mathrm{M}$; pI markers. Correspondence of bands (a)-(e) to each $S$ allele $\left(S_{2}, S_{4}\right.$ and $\left.S_{5}\right)$ was examined based upon the analysis in Experiment 1.

$\left(\mathrm{S}_{1} \mathrm{~S}_{2}\right)$, 'Meigetsu' $\left(\mathrm{S}_{1} \mathrm{~S}_{5}\right)$, 'Ichiharawase' $\left(\mathrm{S}_{1} \mathrm{~S}_{5}\right)$ and 'Okusankichi' $\left(\mathrm{S}_{5} \mathrm{~S}_{7}\right)$. The variety, 'Gion' $\left(\mathrm{S}_{2} \mathrm{~S}_{4}\right)$ which has the $S_{4}$ allele, did not have the (a) band. Thus, no correspondence was evident for the (a) band in six varieties. On the (c) band, correspondence to the $S_{4}$ allele was evident in 15 varieties but absent in two varieties: 'Meigetsu' which has no $S_{4}$ allele $\left(S_{1} S_{5}\right)$, and 'Wasechojuro', which has an $S_{4}$ allele $\left(S_{2} S_{4}\right)$. No correspondence was evident for the (d) band among a total of eight varieties. Four varieties have the $\mathrm{S}_{4}$ allele, but no (d) band, viz. 'Yakumo' $\left(\mathrm{S}_{1} \mathrm{~S}_{4}\right)$, 'Wasechojuro' $\left(\mathrm{S}_{2} \mathrm{~S}_{4}\right)$, 'Rokugatsu' $\left(\mathrm{S}_{2} \mathrm{~S}_{4}\right)$, 'Asahi' $\left(\mathrm{S}_{4} \mathrm{~S}_{5}\right)$. Four varieties have no $S_{4}$ allele, viz. 'Meigetsu' $\left(S_{1} S_{5}\right)$, 'Ichiharawase' $\left(\mathrm{S}_{1} \mathrm{~S}_{5}\right)$, 'Imamuraaki' $\left(\mathrm{S}_{1} \mathrm{~S}_{4}\right)$ and 'Okusankichi' $\left(S_{5} S_{7}\right)$. Elsewhere, on the (b) band, corresponding to the $S_{2}$ allele, the band was found in eight varieties with the $S_{2}$ allele. However, among 13 varieties with no $\mathrm{S}_{2}$ allele, the (b) band existed in eight varieties but in five varieties. Thus no correspondence appeared among eight of the 13 varieties which have no $S_{2}$ allele.
The band pattern of 'Osa-Nijisseiki', a selfcompatible mutant of 'Nijisseiki', exhibited major and minor bands. However, no noteworthy differences appeared between the two varieties. 'Kiyozumi' is a sprout mutant of 'Shinsui' and is self-incompatible. These two had some differences on the minor bands, but the major bands were completely identical.

When compared with Experiment 1 on the four major varieties, the foregoing results revealed correspondences to $S_{4}$ and $S_{2}$ alleles in the intervals from $\mathrm{pH} 4.5$ to $\mathrm{pH} 6$ and from $\mathrm{pH} 5$ to $\mathrm{pH} 8$. Nevertheless, among the total of 21 varieties, no variety demonstrated perfect correspondence between its alleles and the (a), (c), (d) and (b) bands. On the (c) band corresponding to the $\mathrm{S}_{4}$ allele, 'Wasechojuro' $\left(\mathrm{S}_{2} \mathrm{~S}_{4}\right)$, one of the 14 varieties with the $S_{4}$ allele, had no band. Among the seven varieties without the $S_{4}$ allele, one variety, 'Meigetsu' $\left(\mathrm{S}_{1} \mathrm{~S}_{5}\right)$ had the band. Thus among the 21 varieties, two varieties yielded no correspondence to the $S_{4}$ allele.

However, upon examination of the (a) and (d) bands of the 21 varieties for $\mathrm{S}_{4}$ allele correspondence, five varieties had no (a) band, and six varieties had no (d) band. $S_{4}$ allele correspondence on the (a) and (d) bands was relatively low. However, there is relatively high correspondence between the $\mathrm{S}_{4}$ allele and the (c) band. In the examination of the (b) band for correspondence with the $S_{2}$ allele, eight varieties among 13 varieties with no $S_{2}$ allele had the (b) band.

\section{Discussion}

Based upon the result of electrophoresis of stylar proteins, the correspondence of the protein bands to the S-alleles were analyzed among 21 varieties of Japanese pear. The protein at pI 5.3 appeared to have a high probability of correspondence with the $\mathrm{S}_{4}$ allele-associated protein; however, the correspondences were inconclusive in two varieties. Although the $\mathrm{S}$ genotype of each variety used in this study was based upon several previous genetic analyses (Terami et al., 1946; Ogaki, 1958; Machida, 1972), the genotypes of some of the varieties, especially the older varieties, are still indefinite. According to Kajiura and Satoh (1990) who recorded more than one thousand cultivars of local and bred varieties, several names are given according to the locale; therefore, the 


\begin{tabular}{|c|c|}
\hline Variety & S-alleles \\
\hline Doitsu & $\mathrm{S}_{1} \cdot \mathrm{S}_{2}$ \\
\hline Hayatama & Si S2. \\
\hline Yakumo & Si. S'. \\
\hline Meigetsu & Si S5. \\
\hline Ichiharawase & S1 S51 \\
\hline Imamuraaki & Si S6 \\
\hline Chojuro & S2S 3. \\
\hline Wasechojuro & $\mathrm{S}_{2} \mathrm{~S}_{4}$ \\
\hline Rokugatsu & ${\mathrm{S} 2 \mathrm{~S}_{4}}_{4}$ \\
\hline Gion & ${\mathrm{S} 2 \mathrm{~S}_{4}}_{4}$ \\
\hline Kikusui & $\mathrm{S} 2 \mathrm{~S} 4_{4}$ \\
\hline Nijisseiki & ${\mathrm{S} 2 \mathrm{~S}_{4}}_{\mathrm{H}}$ \\
\hline Osa-Nijisseiki & $\mathrm{S} 2 \mathrm{~S}_{4} \mathrm{sm}$ \\
\hline Taihaku & S4 S5 \\
\hline Hakko & S4 45 \\
\hline Kosui & $\mathrm{S}_{4} \mathrm{~S}_{5}$ \\
\hline Shinsui & $\mathrm{S}_{4} \mathrm{~S}_{5}$ \\
\hline Kiyozumi & $\mathrm{S}_{4} \mathrm{~S}_{5}$ \\
\hline Waseaka & S4 S5 \\
\hline Asahi & $\mathrm{S}_{4} \mathrm{~S}_{5}$ \\
\hline Seiryu & $545_{5}$ \\
\hline Okusankichi & S5. S7. \\
\hline
\end{tabular}

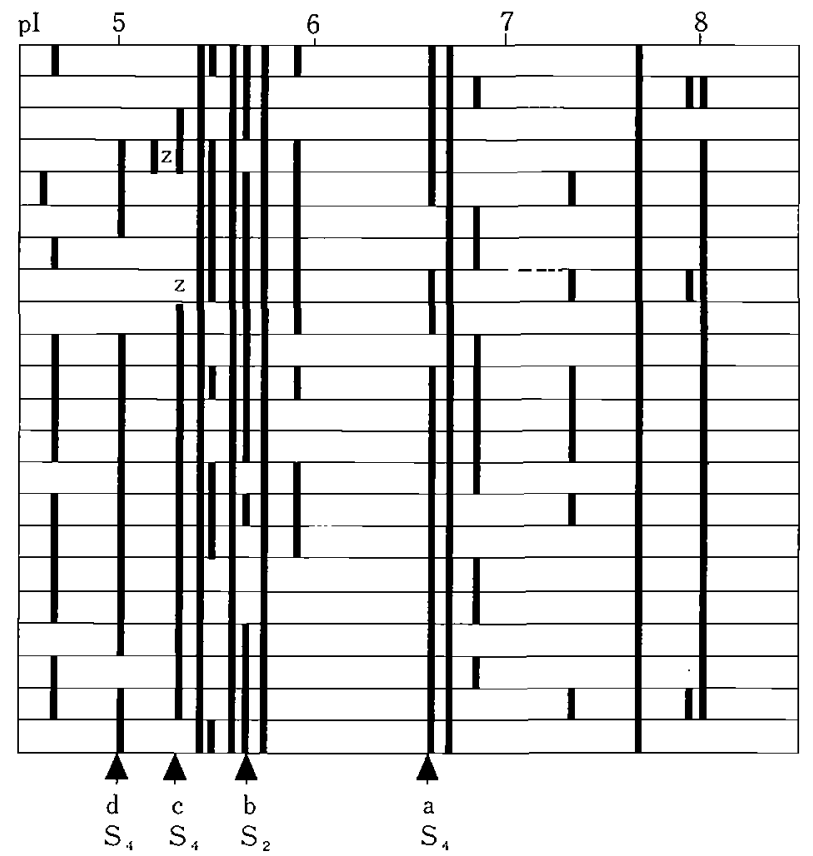

Fig. 6. Major bands pattern of stylar proteins resulted from IEF-PAGE of 22 varieties of Japanese pear. Bands (a), (c) and (d) correspondence to the $S_{4}$ allele, and band (b) to the $S_{2}$ allele, respectively are shown based upon the analysis in Experiment 1.

z These are the varieties which do not correspond with the (c) band to the $S_{4}$ allele. The variety 'Meigetsu' without $S_{4}$ allele showed the band, while the variety 'Wasechojuro' with $S_{4}$ allele showed no band.

same names have been given to different varieties. In collection and conservation, it is sometimes very difficult to identify the origins of the varieties, especially where there has been a transfer or introduction of varieties. This causes some confusion in the study of $\mathrm{S}$ genotypes. However, it is not yet clear whether such confusion has occurred in the varieties used in this study. Thus, the $\mathrm{S}$ genotypes of the varieties need to be reconfirmed by crossing the varieties.

Hiratsuka et al. (1986) reported that two kinds of stylar proteins in 'Chojuro' (with pI 6.0 and 6.1, molecular weight 52,000 and 58,000 , respectively) appeared in conjunction with floral bud development. In contrast, our IEF pattern for 'Chojuro' $\left(\mathrm{S}_{2} \mathrm{~S}_{3}\right)$ exhibits a band near pI 5.9 where the correspondence to the $\mathrm{S}$ genotypes remains unclear. Further examination is necessary to compare the critical pI points of proteins for those results with regard to the methods involved both in the IEF and in the preparation of the sample.
Recently, the characteristics of S-proteins have been found for many plants (Nishio and Hinata, 1977; Bredemeijer and Blass, 1981; Mau et al., 1982; Anderson et al., 1986; Kamboj and Jackson, 1986; Mau et al., 1986; Broothaerts et al., 1989; Jahnen et al., 1989; Kirch et al., 1989; Ai et al., 1990; Xu et al., 1990). Noteworthy among these works, IEF was first applied to identify the proteins associated with S-alleles in Brassica oleracea with different pIs from 5.7 to 11.1 (Nishio and Hinata, 1977). SDS-PAGE was also useful in identifying S-proteins of different molecular weights in Petunia hybrida. Then their pIs were determined by IEF in different pIs from 8.3 to 8.7 (Kamboj and Jackson, 1986). From the evidence that most S-proteins were basic, two-dimensional electrophoresis and its more precise application, selective two dimensional electrophoresis, were developed to detect S-protein in Nicotiana alata (Anderson et al., 1986) and Lycopersicon peruvianum (Mau et al., 1986) above which used pI 9.5 as the selective 
region. According to a recent paper by Kirch et al. (1989), a non-equilibrated $\mathrm{pH}$-gradient electrophoresis (NEPHGE), a two-dimensional electrophoresis for highly basic proteins, isolated the S-proteins of Solanum tuberosum. As a result, they identified three kinds of highly basic S-proteins ranging from pI 8.3 to 9.1 , which had molecular weights ranging from 23,000 to 29,000 .

In our experiment, IEF-PAGE was eventually more effective in separating a large number of stylar proteins than the preliminary study with SDSPAGE. The bands were distributed primarily in the acidic to neutral region, where only the band at pI 5.3 was considered to be associated with $S_{4}$ allele. Therefore, in analyzing the other S-proteins of Japanese pear, methods such as selective two dimensional electrophoresis or NEPHGE might be necessary to separate the dense, discrete bands still focused near the basic end for each variety. Thus, a more efficient range of pIs or molecular weights in electrophoresis must be considered in order to identify the S-proteins.

From the perspective of molecular weights of the S-proteins, it seems evident that Solanaceae plants which are all governed by gametophytic SI, e.g., Nicotiana alata (Kheyr-Pour and Pernes, 1986), Petunia hybrida (Kamboj and Jackson, 1986), Solanum tuberosum and chacoense (Kirch et al., 1989, $\mathrm{Xu}$ et al., 1990) and Lycopersicon peruvianum (Mau et al., 1986), have molecular weights of approximately 30,000 . Also, these Solanaceae plants have significantly smaller molecular weights than those of sporophytic types, e.g., Brassica, at approximately 60,000 (Nishio and Hinata, 1982). In Rosaceae, an immuno-electrophoresis performed on Prunus avium which is also governed by gametophytic SI, disclosed S-proteins with molecular weights from 32,000 to 37,000 , and pIs from 9.5 to 10.4 (Mau et al., 1982). In addition to the above results on the molecular weights, high homology in the amino acid sequencing of the $\mathrm{S}$ proteins has been reported in the gametophytic plants, including Petunia inflata, Petunia hybrida, Nicotiana alata and Lycopersicon peruvianum (Ai et al., 1990). Such a comparison of the S-proteins in a gametophytic SI plant may contribute to further analyses of the Sproteins in Japanese pear.

In this experiment, the stylar protein of the selfcompatible variety 'Osa-Nijisseiki' was examined with comparsion to the self-incompatible variety
'Nijisseiki'. Most probably, 'Osa-Nijisseiki' acquired self-compatibility by the mutation of the stylar part of the $\mathrm{S}_{4}$ gene of 'Nijisseiki' (Satoh et al., 1988). In these two varieties, the behavior of the protein bands was interesting, however the results of the IEF-PAGE in this pair of varieties did not differ at all in this experiment. Further research may be necessary to verify how the stylar mutation of 'Osa-Nijisseiki' relates to the S-protein level.

\section{Literature Cited}

Ai, Y., A. Singh, C.E. Coleman, T.R. Ioerger and A. Kheyr-Pour. 1990. Self-incompatibility in Petunia inflata: Isolation and characterization of c-DNAs encoding three S-allele-associated proteins. Sex. Plant Reprod. 3: 130-138.

Anderson, M.A., E.C. Cornish, S.-L. Mau, E.G. Williams, R. Hoggart, P.J. Roche, J.D. Penshow, H.D. Niall, G.W. Tregear, J.P. Coghlan, R. J. Crawford and A.E. Clarke. 1986. Cloning of cDNA for a stylar glycoprotein associated with expression of self-incompatibility in Nicotiana alata. Nature $321: 38-44$.

Asami, Y. and F. Hayami. 1934. The growth of pollentubes in incompatible pollinations of Japanese pears. J. Japan. Soc. Hort. Sci. 5:222-232.

Bredemeijer, G.M.M. and J. Blaas. 1981. S-specific proteins in styles of self-incompatible Nicotiana alata. Theor. Appl. Genet. 59:185-190.

Broothaerts, W.J., A. von Laere, R. Witters, G. Preaus, B. Decock, J. van Damme and J.C. Vendrig. 1989. Purification and $\mathrm{N}$-terminal sequencing of style glycoproteins associated with self-incompatibility in Petunia hybrida. Plant Molecular Biology $14: 93-102$.

Du Nettancourt, D. 1977. Incompatibility in angiosperms. p. 75-81. In: Frankel (ed.). Monographs on theoretical and applied genetics. vol 3. SpringerVerlag, Berlin, Heiderberg, New York.

East, E.M. and A.J. Mangelsdorf. 1925. A new interpretation of the hereditary behavior of self-sterile palnt. Proc. Natn. Acad. Sci. U.S.A. 11 : 166-171.

Hirata, N., S. Hayashi and H. Kobayashi. 1973. Studies of the self- and cross-incompatibility in the Japanese pear. I. Effect of substances extracted from the style and the pistil on the pollen germination and the tube growth. Abstr. Japan. Soc. Hort. Sci. Spring Meet.: 118-119. (In Japanese).

Hiratsuka, S., K. Ichimura, E. Takahashi and N. Hirata. 1986. Analysis of proteins in developing style and ovary with reference to self-incompatibility of Japanese pear. J. Japan. Soc. Hort. Sci. $55: 145-152$.

Iimori, M. 1933. Studies on the pollination and fertili- 
zation of Japanese pear. Bull. Okitsu Hort. Exp. Stn. 29 : 166-187. (In Japanese).

Inose, T. 1964. Physiological studies on the features of fruiting in the Japanese pear Chojuro. Bull. Saitama Agri. Exp. Stn. $24: 1-86$. (In Japanese).

Jahnen, W., M.P. Batterham, A.E. Clarke, R. L. Moritze and R.J. Simpson. 1989. Identification, isolation, and $\mathrm{N}$-terminal sequencing of style glycoproteins associated with self-incompatibility in Nicotiana alata. Plant Cell $1: 493-499$.

Kajiura, I. and Y. Satoh, 1990. Recent progress in Japanese pear (Pyrus pyrifolia Nakai) breeding, and descriptions of cultivars based on literature review. Bull. Fruit Tree Res. Stn. Extra No. 1:1-329. (In Japanese).

Kamboj, R.K. and J.F. Jackson. 1986. Selfincompatibility alleles control a low molecular weight, basic protein in pistils of Petunia hybrida. Theor. Appl. Genet. $71: 815-819$.

Kawaguchi, M. and H. Samune. 1935. Cross fertility and sterility in the Japanese pear, specially in the new varieties. J. Japan. Soc. Hort. Sci. $6: 288-293$. (In Japanese).

Kawata, Y., F. Sakiyama, F. Hayashi and Y. Kyogoku. 1990. Identification of two essential histidine residues of ribonuclease T2 from Aspergillus oryzae. Eur. J. Biochem. $187: 255-262$.

Kheyr-Pour, A. and J. Pernes. 1986. A new S-allele and specific S-proteins associated with two S-alleles in Nicotiana alata p. 191-196. In: Mulcahy, Mulcahy and Ottaviano (ed.). Biotechnology and ecology of pollen. Springer, Berlin, Heidelberg, New York.

Kikuchi, A. 1928. Self and cross-sterility in the Japanese pear. Mem. Hort. Soc. N.Y. $3: 233-241$.

Kikuchi, A. 1929. Investigations in 1927 and 1928. Paterclinal incompatibility in the Japanese pear. Okitsu Hort. Soc. 24 : 1-6. (In Japanese).

Kirch, H.H., H. Uhrig, F. Lottspeich, F. Salamini and R.D. Thompson, 1989. Characterization of proteins associated with self-incompatibility in Solanum tuberosum. Theor. Appl. Genet. 78:581-588.

Lewis, D. $1952 . \quad$ Serological reactions of pollen incompatibility substances. Proc. Roy. Soc. London, Series B $140: 127-135$.

Linskens, H.F. 1960. Zür Frage der Entstehung der Abwehr Körper bei der Inkompatibilitätsreaktion von Petunia. III. Mitteilung: Serologische Teste mit Leitgewebs- und Pollen-Extrakten. Naturwissensch. $46: 547$.

Machida, Y. 1972. Morphological and physiological characteristics of Japanese and Chinese pear. p. 527-529. In: Satoh (ed.). Dictionary of pomology. Yokendo, Tokyo. (In Japanese).

Mau, S.L., J. Raff and A.E. Clarke. $1982 . \quad$ Isolation and partial characterization of components of Prunus avium $\mathrm{L}$. styles, including an antigen glycoprotein associated with a self-incompatibility genotype. Planta $156: 505-516$.

Mau, S.L., E.G. Williams, A. Atkinson, M.A. Anderson, E.C. Cornish, B. Grego, R. J. Simpson, A. KheyrPour and A.E. Clarke. 1986. Style proteins of wild tomato (Lycopersicon peruvianum) associated with expression of self-incompatibility. Planta $169: 184-191$.

McClure, B. A., V. Haring, P. R. Ebert, M. A. Anderson, R. J. Simpson, F. Sakiyama and A.E. Clarke. 1989. Style self-incompatibility gene products of Nicotiana alata are ribonucleases. Nature 342:955-957.

Nasrallah, J.B., T.H. Kao, M.L. Goldberg and M.E. Nasrallah. 1985. A cDNA clone encoding an Slocus-specific glycoprotein from Brassica oleracea. Nature 318: 263-267.

Nasrallah, M.E. and J.B. Nasrallah. 1986 . Molecular biology of self-incompatibility in plants. Trends in Genetics 2:239-244.

Nishio, T. and K. Hinata. 1977. Analysis of S-specific protein in stigma of Brassica oleracea L. by IEF. Heredity $38: 391-396$.

Nishio, T. and K. Hinata. 1982. Comparative studies on S-glycoproteins purified from different S-genotype in self-incompatible Brassica species. I. Purified and chemical properties. Genetics $100: 641-647$.

Ogaki, C. 1958. The sterility-factors in new varieties of the Japanese pear (Pyrus serotina Rhed. var. culta Rhed.). Res. Rep. Kanagawa Agri. Inst. Hort. 5: 23-26. (In Japanese).

Satoh. Y., A. Kurihara, K. Abe, T. Ogata, I. Kajiura, K. Kotobuki and Y. Machida. 1988. Genetical analysis of the self-compatibility in Japanese pear. Abstr. Japan. Soc. Hort. Sci. Autumn Meet.: 76-77. (In Japanese).

Sobajima, Y., M. Ishida, M. Nakagawa, T. Fujiwara, S. Iimuro and K. Kiyokawa. 1973. Studies on the self-incompatibility in Japanese pear Chojuro. Abstr. Japan. Soc. Hort. Sci. Autumn Meet.: 14-15. (In Japanese).

Takayama, S., A. Isogai, C. Tsukamoto, Y. Ueda, K. Hinata, K. Okazaki and A. Suzuki. 1986. Isolation and some characterization of S-locus-specific glycoproteins associated with self-incompatibility in Brassica campestris. Agric. Biol. Chem. $50: 1365-1367$.

Takayama, S., A. Isogai, C. Tsukamoto, Y. Ueda, K. Hinata, K. Okazaki and A. Suzuki. 1987. Sequences of S-glycoproteins, products of the Brassica campestris self-incompatibility locus. Nature $326: 102-105$.

Takeo, T. and I. Uritani. 1976. Tea leaf polyphenol oxidase. Part II. Purification and properties of the solubilized polyphenol oxidase in tea leaves. Agr. Biol. Chem. $30: 155-163$.

Terami, H. 1937. Histological, physiological and genet- 
ical studies of self- and cross-sterility in the Japanese pear. Studies Hort. Inst. Kyoto Imp. Univ. 2 : 1-52. Terami, H., H. Torikata and Y. Shimazu. 1946. Analysis of the sterility-factors existing in varieties of the Japanese pear (Pyrus serotina Rehd. var. culta Rehd). Studies Hort. Inst. Kyoto Imp. Univ. $3: 267-271$. (In Japanese).

Ushigoshi, M. and K. Tokuyasu. 1930. Studies on pollination and fertilization of pears. J. Okitsu Hort.
Soc. $25: 135-152$. (In Japanese).

Xu, B., P. Grun, A. Kheyr-Pour and T.H. Kao. 1990. Idenfification of pistil-specific proteins associated with three self-incompatibility alleles in Solanum chacoense Sex. Plant Reprod. 3:54-60.

Zacharius, R.M. 1969. Glyco-protein staining following electrophoresis on acrylamide gels. Anal. Biochem. $30: 148-152$.

\title{
ニホンナシ自家不和合性の S 遺伝子に対応する花柱タンパク質の分析 \\ 中西テッ1 $\cdot$ 山崎忠寛 ${ }^{1 *} \cdot$ 船寺佳奈子 ${ }^{1 * *} \cdot$ 朝長晴代 ${ }^{1 * * *}$. \\ 尾崎武 1 河合義隆 ${ }^{1 * * * *} \cdot$ 一井隆夫 ${ }^{1 * * * * *} \cdot$ 佐藤義彦 $^{2} \cdot$ 栗原昭夫 $^{2 * * * * * *}$ \\ 1神戸大学曟学部 657 神戸市灘区六甲台町 \\ 2農林水産省果樹試験場 305 茨城目つくば市藤本
}

\begin{abstract}
摘要
自家不和合性の複対立遺伝子が知られているニホン ナシ22品種（自家和合性 1 品種を含む）の花柱タンパ ク質を等電点電気泳動 (IEF-FAGE) で分離し, S 遺 伝子に対応するタンパク質の分析を試みた。はじめに 実験 1 とし, 主要栽培品種（“幸水” $\mathrm{S}_{4} \mathrm{~S}_{5}$, ‘新水” $\mathrm{S}_{4} \mathrm{~S}_{5}$, “長十郎' $\mathrm{S}_{2} \mathrm{~S}_{3}$, ‘二十世紀' $\mathrm{S}_{2} \mathrm{~S}_{4}$ ) について $\mathrm{pH} 3 \sim 10$, 5 ～8 および 4 〜 6.5の領域でIEFを行った結果, p16.6 (a)， 5.3 (c)，5.0 (d)のバンドは $\mathrm{S}_{4}$ 遺伝子と, p15.6 (b) と6.0 (e) はそれぞれ $\mathrm{S}_{2}$ 抢よび $\mathrm{S}_{5}$ 遺伝子に 対応するとみられた。これらのバンドはいずれも PAS 反応に陽性を示し，糖タンパク質であることが示唆さ

れた．実験 2 ではさらに18品種の分析を行った。実験 1 で想定された $\mathrm{S}$ 遺伝子型 $\left(\mathrm{S}_{5}\right.$ を除く)とタンパクバ ンドの関係について，実験 1 および2の21品種（自家 和合性品種を除く）の結果を総合した．その結果（c） バンドは19品種において $\mathrm{S}$ 遺伝子と対応関係がみられ, $\mathrm{S}_{4}$ 遺伝子に関連するタンパク質である可能性が示唆さ れた。他のバンドのS 遺伝子型と品種の対応関係はそ れぞれ(a)バンド15品種，(b)バンド13品種および(d) バンド13品種であった. 自家和合性品種の゙二十世紀’と その花柱側遺伝子の突然変異とみられている゙おさ二十 世紀のバンドパターンには差がみられなかった。
\end{abstract}

\footnotetext{
* 現在：塩野義製薬.

** 現在：兵庫県。

*** 現在：住友化学.

**** 現在: 三重大学.

***** 現在: 関西女学院短期大学.

****** 現在：国際協力事業団派遣長期専門家.
} 